\title{
Genetic variability of hepatitis A virus strain HAF-203 isolated in Brazil and expression of the VP1 gene in Escherichia coli
}

\author{
Marcia L Baptista/ ${ }^{+}$, Messias Silva, Maria Amélia de Lima, Clara FT Yoshida, \\ Ana Maria C Gaspar*, Ricardo Galler**
}

\begin{abstract}
Laboratório de Hepatites Virais *Laboratório de Desenvolvimento Tecnológico, Departamento de Virologia **Laboratório de Biologia Molecular de Flavivírus, Departamento de Bioquímica e Biologia Molecular, Instituto Oswaldo Cruz-Fiocruz,
\end{abstract}

Av. Brasil 4365, 21040-900 Rio de Janeiro, RJ, Brasil

The hepatitis A virus (HAV) HAF-203 strain was isolated from an acute case of HAV infection. The primary isolation of HAF-203 in Brazil and its adaptation to the FRhK-4 cell lineage allowed the production of large amounts of viral particles enabling molecular characterization of the first HAV isolate in Brazil. The aim of our study was to determine the nucleotide sequence of the HAF-203 strain genome, compare it to other HAV genomes and highlight its genetic variability. The complete nucleotide sequence of the HAF-203 strain (7472 nucleotides) was compared to those obtained earlier by others for other HAV isolates. These analyses revealed 19 HAF-specific nucleotide sequence differences with 10 amino acid substitutions. Most of the non-conservative changes were located at VP1, $2 C$, and $3 D$ genes, but the $3 B$ region was the most variable. The availability of HAF-203 complementary DNA was useful for the production of the recombinant VP1 protein, which is a major determinant of viral infectivity. This recombinant protein was shown by enzyme-linked immunoassay and blotting, to be immunogenic and resemble the native protein, therefore suggesting its value as a reagent for incorporation into diagnostic tests.

Key words: hepatitis A virus (HAV) - HAF-203 strain - complete genome (Brazil) - VP1 gene recombinant protein Escherichia coli expression - HAV diagnosis

The hepatitis A virus (HAV) is the causative agent of an old and common human disease, with high incidence rates, still present in many countries throughout the world. In Brazil, this disease has been responsible for $50 \%$ of the acute hepatitis cases referred to the National Reference Center for Viral Hepatitis/Oswaldo Cruz Institute/Ministry of Health. The etiological agent was first identified by Feinstone et al. (1973), and the virus is currently classified as the first and unique member of the genus Hepatovirus, Picornaviridae family (Minor 1991).

$\mathrm{HAV}$ is a $27-\mathrm{nm}$ non-enveloped icosahedral particle, which comprises a single stranded plus-sense RNA (Coulepis et al. 1981). The viral genome is composed of approximately 7500 nucleotides, edged by a covalently linked VPg protein at the 5 ' terminal and a polyadenylated 3 ' end. The viral RNA encodes a single polyprotein of 2224 amino acids, which is later cleaved into 11 viral polypeptides (Cohen et al. 19847a).

The Brazilian HAF-203 strain investigated here was obtained from a faecal specimen of an acute hepatitis A patient. The viral isolation and serial passage history was previous reported by Gaspar et al. (1992). The HAF-203 HAV strain was inoculated into fetal Rhesus kidney cells (FRhK-4) and then reinoculated into new cultures on the 28th day and subsequently every 35 days, using tissue culture fluid (TCF) as inoculum. An HAV antigen could

${ }^{+}$Corresponding author: marcialb@ioc.fiocruz.br Received 26 April 2006

Accepted 31 July 2006 be demonstrated in TCF 49 days after inoculation, applying enzyme immunoassays (EIA), immunofluorescence (IF), and hybridisation tests. In addition, HAV replication was demonstrated by the detection of viral replicative intermediate (minus strand), employing reverse transcription followed by polymerase chain reaction (RTPCR) (Baptista ML et al. unpublished). In the present study, we have sequenced the complete genome of the HAF-203 HAV strain and compared it with other HAV isolates. Several groups have adopted recombinant viral proteins for diagnostic purposes (Ostermayer et al. 1987, Johnston et al. 1988, LaBrecque et al. 1998, Ternovai et al. 2001, Di Napoli et al. 2004). A fragment of the HAF-203 strain encoding the complete VP1 gene was cloned and expressed in Escherichia coli, to provide valuable specific immune reagents for both diagnostic and epidemiological surveys of HAV infection.

\section{MATERIALS AND METHODS}

Virus - Virus from the 4th passage in FrhK-4 cells was purified from culture medium and infected cells. Culture medium was collected weekly, during 28 days, and stored at $-20^{\circ} \mathrm{C}$. Monolayer infected cells $(28$ th passage after inoculation) were suspended in lysis buffer $(10 \mathrm{mM}$ Tris buffer $\mathrm{pH} 7.5$ containing $50 \mathrm{mM} \mathrm{NaCl}, 0.5 \% \mathrm{NP} 40,0.5 \%$ deoxycholic acid, and sodium salt - DOC) then frozen and thawed three times. The cellular extracts were centrifuged at $6000 \mathrm{~g}$ for $10 \mathrm{~min}$ and re-extracted twice with lysis buffer. Culture medium and cellular extracts were combined and precipitated, using $0.3 \mathrm{M} \mathrm{NaCl}-10 \%$ polyethylene glycol 6000 . The mixture was stirred at $4^{\circ} \mathrm{C}$ overnight, and the precipitate was collected by centrifugation at $10,000 \mathrm{~g}$ for $30 \mathrm{~min}$. The supernatant was discarded, and the precipi- 
tate was suspended in $10 \mathrm{mM}$ Tris buffer (pH 7.5), containing $50 \mathrm{mM} \mathrm{NaCl}$ and $1 \mathrm{mM}$ EDTA(TNE buffer). Anew extraction was carried out using trichlorotrifluoroethane (FREON), and the aqueous phase was separated by centrifugation at $5000 \mathrm{~g}$ for $10 \mathrm{~min}$. The aqueous phase was reserved, and the FREON phase and interface were reextracted three times with TNE. The extracts and aqueous phases were pooled and layered into a $11.5 \mathrm{ml}$ linear gradient, prepared on top of a $0.5 \mathrm{ml} 30 \%$ sucrose cushion. All sucrose solutions were prepared in $10 \mathrm{mM}$ Tris ( $\mathrm{pH} 7.4)$ $1 \mathrm{M} \mathrm{NaCl}$. After centrifugation at $38,000 \mathrm{~g}$ for $4 \mathrm{~h}$, the concentrated virus was ressuspended in $500 \mu \mathrm{l}$ of TNE bufferRNase free. The aliquots were tested by EIA and then stocked at $-70^{\circ} \mathrm{C}$ until use.

RNA extraction - Sodium dodecyl sulphate (SDS) and $\beta$-mercaptoethanol in a final concentration of $1 \%$ were added to every aliquot of HAF-203 strain concentrated in sucrose cushion. RNA extraction was performed applying phenol-chloroform followed by ethanol precipitation.

cDNA synthesis (reverse transcription) and PCR 1 A total of 28 specific primers (Table) were employed for reverse transcription and cDNA amplification by PCR. For complementary DNA (cDNA) synthesis, RNA was ressuspended in water and mixed with negative-sense primer (0.1 pmol), corresponding to HAV nucleotide sequences. After heating at $90^{\circ} \mathrm{C}$ for $2 \mathrm{~min}$ and slow cooling down to room temperature ( $5 \mathrm{~min}$ ), reverse transcription was carried out for $60 \mathrm{~min}$ at $37^{\circ} \mathrm{C}$, using the reaction mixture: 50 $\mathrm{mM}$ Tris- $\mathrm{HCl} \mathrm{pH}$ 7.3, $50 \mathrm{mM} \mathrm{KCl}, 10 \mathrm{mM} \mathrm{MgCl}, 5 \mathrm{mM}$ DTT, $0.2 \mathrm{mM}$ each deoxynucleotide, $400 \mathrm{U} / \mathrm{ml}$ Rnasin (BRL), and $200 \mathrm{U} / \mathrm{ml}$ MMLV- RT (BRL). cDNA synthesis was discontinued by heating at $65^{\circ} \mathrm{C}$ for $10 \mathrm{~min}$. The RT product was mixed with an equal volume of a solution containing $0.2 \mathrm{mM}$ deoxynucleotides, 20 pmol of each pair of positive- and negative-sense synthetic oligonucleotides and $1 \mathrm{U}$ Taq DNA polymerase (BRL). After overlaying reaction mixtures with paraffin oil, PCR was performed as previously described (Saiki et al. 1988), using 35 consecutive cycles with a 1 -min denaturation step $\left(92^{\circ} \mathrm{C}\right)$, a 1 min renaturation step $\left(45^{\circ} \mathrm{C}\right)$, and a 3 min-polymerisation $\operatorname{step}\left(72^{\circ} \mathrm{C}\right)$.
PCR 2 - The first PCR products were isolated by electrophorectic separation on low-melting temperature agarose (Sigma), and a second PCR was carried out following the same protocol, except for the number of cycles ( 25 cycles).

Cloning - The PCR 2 products were cloned into a pGEM 2 (Promega) or pCRII (Invitrogene) plasmids. For the recombinant protein expression, a fragment carrying the VP1 gene was cloned into a pET28a plasmid (Novagen).

Sequencing - Nucleotide sequencing was performed according to the dideoxy termination method (Sanger et al. 1977) using SP6 and T7 primers (Promega). Sequenase (USB) and [32P] dATP (ICM) were utilized, according to manufacturer's specifications. Sequencing reactions were submitted to electrophoresis in $0.4 \mathrm{~mm}$-thick Tris-BorateUrea gels and visualized by autoradiography. At least two clones of each region were sequenced on both strands consisting of 12 clones and 13 sub-clones along the 7500 nucleotides of the HAF-203 genome. When differences were observed, additional clones were evaluated.

Nucleotide sequence analysis - For this purpose, we selected one complete nucleotide sequence from each HAV (genotype I) including the HM-175 strain from Australia (Cohen et al. 1987b) GenBank accession number M14707, to which the nucleotide sequence of its attenuated derivative (Cohen et al. 1987a), accession M16632, was also included. The other sequences, available in databanks, were: the LA strain from Los Angels/US (Najarian et al. 1985) accession K02990; the MBB strain from Africa (Paul et al. 1987) accession M20273; the HAS15 strain from US (Sverlov et al. 1987) accession X15464 and X15463; the GBM strain from Germany (Graft et al. 1994) accession X75215; the HAV-FG strain from Italy (Beneduce et al. 1995) accession X83302. All analyzed strains were adapted to cell cultures. The HAF-203 nucleotide GenBank accession number is AF268396. Sequence analysis was performed, adopting the "Seqed and Fasta" programs (Wisconsin University, Sequence Analysis Package, GCG, Madison, WI), and Clustal X software (Thompson et al. 1977).

TABLE

List of primer sequences used for cDNA construction and amplification of the HAF-203 strain

\begin{tabular}{|c|c|}
\hline Sense primers & Anti-sense primers \\
\hline + 11-5' gtc.tcc.ggg.aat.ttc.cgg 3 (18 mer) & - 344-5' cac.tgc.aaggtg.acg.ttc.c 3' (19 mer) \\
\hline$+292-5^{\prime}$ agc.atg.gag.ctg.tag.gag.tc $3^{\prime}$ (20 mer) & - 544-5' taa.aga.cag.ccc.tga.cag.tc $3^{\prime}$ (20 mer) \\
\hline +535 - 5' gag.tgg.att.gac.tgt.cag.g 3' (19 mer) & - 937 - 5' ccg.ggt.tta.tca.aca.gag.g 3' (19 mer) \\
\hline$+\mathbf{1 3 8 0}-5^{\prime}$ ggg.aca.gga.act.tca.gc $3^{\prime}(17$ mer $)$ & - 1489 - 5' ctc.agt.agt.act.gac.cc $3^{\prime}$ (17 mer) \\
\hline $\mathbf{+ 2 1 1 4}-5^{\prime}$ cgt.tgc.ttc.cca.tgt.cag $3^{\prime}$ (18 mer) & - 2211 - 5' cct.cca.gaa.tca.tct.cc 3' (17 mer) \\
\hline$+\mathbf{3 2 0 1}-5^{\prime}$ gta.ctt.cca.ccc.cct.agg 3' (18 mer) & - $\mathbf{3 2 9 5}-5^{\prime}$ cag.cag.tca.cag.ctc.tcc 3 ' (18 mer) \\
\hline + $3642-5^{\prime}$ gga.ttg.tct.gga.gtt.cag.g 3' (19 mer) & - $3753-5^{\prime}$ caa.cag.tca.cag.aat.gat.g 3' (19 mer) \\
\hline$+\mathbf{3 9 8 0}$ - 5' gga.gtt.aag.gac.tca.gag 3' (18 mer) & - 4167 -5' cat.cgg.ctt.cct.caa.tgg.c 3' (19 mer) \\
\hline + $4658-5$ ' ggc.ctc.tct.tga.gga.gaa.g 3' (19 mer) & - $4764-5^{\prime}$ gaa.atg.gag.tct.gcg.ctg $3^{\prime}$ (18 mer) \\
\hline + 5371 - 5' ggg.tta.tga.atg.cct.tgg.g 3' (19 mer) & - 5529 - 5' caa.cat.cct.gga.atc.cca.c 3' (19 mer) \\
\hline +5699-5' gat.gca.aga.gaa.agc.tac 3' (18 mer) & $\mathbf{- 5 8 4 7}-5^{\prime}$ cat.gga.tgc.cca.aga.ttg.c $3^{\prime}$ (19 mer) \\
\hline$+\mathbf{6 0 5 7}-5^{\prime}$ cct.gca.gct.atg.ccc.ttt.tc $3^{\prime}(20$ mer $)$ & - 6294 - 5' ggt.caa.ctt.ctc.ctg.gac 3' (18 mer) \\
\hline$+6747-5^{\prime}$ cta.tct.gga.act.cca.tcc.c 3' (19 mer) & - 6844 - 5' gga.gac.cca.gag.ggc.att.g 3' (19 mer) \\
\hline$+\mathbf{7 4 0 5}-5^{\prime}$ gtg.acc.ttt.cat.gat.ttg $3^{\prime}(18$ mer $)$ & - 7461 - 5' att.tac.tca.taa.aag.aaa $3^{\prime}$ (18 mer) \\
\hline
\end{tabular}


Phylogenetic tree - The tree was generated using the Kimura two-parameter model with full-length genomic sequences and neighbor-joining method, MEGA 3.1 version (Kumar et al. 2004). The reliability was assessed by bootstrap re-sampling (1000 pseudo-replicas), also in MEGA. The nucleotide sequences from the following strains were retrieved from GenBank: AGM 27 (D00924), AH1 (AB020564), AH2 ( AB020565), AH3 (AB020566), CF53 (AY644676), DL3 (AF512536), FG (X83302), FH1 (AB020567), FH2 (AB020568), FH3 (AB020569), GBM (X75215, X75214, and X75216), HAF-203 (AF 268396 - this paper), HM-175 (M14707, NC001489), HM-175 attenuated (M16632), HAS-15 (X15464 and X15463), IVA (DQ646426), LA (K02990), LY6 (AF485328), M2 (AY974170), MBB (M20273), NOR-21 (AJ299464), and SLF88 (AY644670).

Bacterial expression - The DNAs encoding the complete VP1 (the major viral antigen), parts of 2A and VP3 HAV proteins were cloned and expressed in E. coli. A 1.2 $\mathrm{Kb}$ fragment (amino acid 461-860) was obtained by enzymatic digestion from the 42pGEMVP1 clone. After digestion with Eco RI and Hind III (restriction sites present in plasmid pGEM2), the fragment was inserted into the expression vector pET28a (Novagen). The resulting plasmid was referred to as VP1pET42u. In addition, a vector control of the expression procedure, plasmid VP1pET85t, was employed. It constituted another $\mathrm{pET}$ construct with the same fragment, not in frame. For bacterial expression of the recombinant protein, E. coli strain BL-21 (DE3) was transformed using the pET28a constructs. The cultures were incubated at $37^{\circ} \mathrm{C}$ in Luria broth, containing kanamicin $(50 \mu \mathrm{g} / \mathrm{ml})$ until $\mathrm{OD}_{600}=0.8$. For the induction step, we added isopropyl- $\beta$-D-thiogalactopyranoside (IPTG) to a final concentrations of $0.2 \mathrm{mM}$. The cultures were incubated overnight at $39^{\circ} \mathrm{C}$. Bacteria were pelleted by centrifugation, ressuspended and extracted by ultrasonication using $0.1 \mathrm{mM}$ of lisozyme. The proteins were precipitated by acetone, solubilized with $6 \mathrm{M}$ urea and concentrated with $30 \%$ ammonium sulphate. The expressed recombinant protein was submitted to electrophoresis- in a $12 \%$ polyacrilamide gel (SDS-PAGE) and tested by Western blot, utilizing a human convalescent-phase anti-HAV serum.

Purification of VP1pET42u and measurement of concentration - The His-tagged recombinant protein was purified by immobilized metal-ion affinity chromatography (IMAC) using six histidine residues added to the carboxi-terminus of the VP1 recombinant protein. Briefly, the His-tagged VP1PET42u was extracted from the bacterial pellet under denaturing condition (6M urea), bound to $\mathrm{Ni}^{2+}$ (Ni-NTA superflow - Qiagen) and eluted with 100 $\mathrm{mM}$ imidazole, following the manufacturer's instructions (The QIAexpressionist Kit - Qiagen). The purified protein solution was quantified by the Lowry method (Lowry et al. 1951), standardized with bovine serum albumin and estimated by molar extinction coefficient at $280 \mathrm{~nm}$.

Rabbit immunization - Rabbits were immunized with the recombinant VP1 protein. The protocol for immuni- zation was adopted as previously described by Camargo et al. (1987). Immune serum was obtained after four 80 $\mu \mathrm{g}$ intramuscular doses of purified recombinant VP1 protein at two week intervals.

Conjugation of anti-HAV rabbit immune serum to horseradish peroxidase - The resulting antiserum was assayed by EIA for the detection of anti-HAV antibodies (Hepanostika HAV Antibody - Biomerieux). Rabbit antiHAV gammaglobulin was precipitated with ammoniun sulphate, according to Hebert et al. (1973). Four milligrams of purified IgG was conjugated to $10 \mathrm{mg} / \mathrm{ml}$ horseradish peroxidase (type IV; Sigma). The Nakane's method was adopted as modified by Carmargo et al. (1987).

Dot Blot - The rabbit HAV antiserum was also analyzed by Dot Blot. Aliquots of $100 \mu$ FRhK-4 cells infected or not with HAF-203 virus were incubated $(1 \mathrm{~h}$ at $\left.65^{\circ} \mathrm{C}\right)$ with $100 \mu$ l of Triton-X100-SDS buffer $(50 \mathrm{mM}$ Tris$\mathrm{HCl} ; 0.1 \%$ Triton-X100 and $2 \%$ SDS) extracted with phenol chloroform $(1: 1, \mathrm{v} / \mathrm{v})$ and once more with chloroform $(1: 1, \mathrm{v} / \mathrm{v})$. Positive and negative feces for HAV antigen were utilized for testing the HAV antiserum. Stool samples were prepared as a $10 \%(\mathrm{w} / \mathrm{v})$ suspension in PBS $\mathrm{pH} 7.2$, clarified by low-speed centrifugation and treated as described above. Samples were boiled at $100^{\circ} \mathrm{C}$ for $5 \mathrm{~min}$ and applied directly to nitrocellulose paper (BioRad) using a Minifold II slot-blot apparatus. After heating for $2 \mathrm{~h}$ at $65^{\circ} \mathrm{C}$ in a vacuum oven, the membrane was incubated in PBST-Milk solution (phosphate buffer - PBS pH 7.2; $0.05 \%$ tween 20 plus $5 \%$ dried non fat milk) for $16 \mathrm{~h}$ at room temperature. The membrane was washed in $15-20 \mathrm{ml}$ PBST (PBS pH 7.2; 0.05\% tween 20) three times and incubated with PBST-Milk solution plus primary antibody (Rabbit HAV antiserum, as described above) at room temperature for $2 \mathrm{~h}$. The membrane was washed three times in 15$20 \mathrm{ml}$ PBST and transferred to PBST-Milk solution containing goat anti-rabbit IgG peroxidase conjugate (Sigma) at $1: 500$ and incubated at $37^{\circ} \mathrm{C}$ for $1 \mathrm{~h}$. After washing three times with PBST, the substrate was added (NBT/ BCIP). Color development was performed in compliance to manufacturer's instructions (Bio-Rad).

Competitive Immunoassay test with rabbit anti-recombinant VP1 horseradish peroxidase conjugate - A standard protocol for the detection of antibodies against HAV was adopted (Vitral et al. 1991) to analyze the rabbit anti-VP1 conjugate. Briefly, a gammaglobulin IgG anti-HAV was used to coat a polystyrene well plate exposed to overnight incubation at $8^{\circ} \mathrm{C}$. Further, an HAF-203 antigen from culture supernatants and positive control sera (anti-HAV $\mathrm{IgG}$ ) were simultaneously added. After incubation and washing steps addition of rabbit anti-VP1-horseradish peroxidase conjugate was succeeded. Tetramethylbenzidine (TMB) plus $\mathrm{H}_{2} \mathrm{O}_{2}$ were employed to reveal the reaction followed by spectrophotometric reading at $450 \mathrm{~nm}$. The cut-off value was defined as the mean of positive and negative control values. Specimens with absorbance values greater than the cut-off value were considered as negative and those with absorbance values lower than or equal to the cut-off were considered as a positive result. 


\section{RESULTS}

Nucleotide and amino acid sequence heterogeneity in the Brazilian HAF-203 strain genome - The 7472 nucleotides of the HAF-203 strain genome were sequenced in both strands and at least two clones for each region were investigated. In the HAF-203 strain, the nucleotide changes were distributed throughout the genome and most of them constituted silent mutations with VP1, 2C, and 3D having accumulated most of the nucleotide and amino acid changes.

Nineteen nucleotide alterations, exclusive to the HAF203 strain, were present along the genome, however only 10 of them resulted in amino acid substitutions. Mutations were observed in the VP3 protein (nucleotide 1574:
$\mathrm{Asp} \rightarrow \mathrm{Val}$ ); VP1 protein (nucleotide 2292: Ile $\rightarrow$ Met, nucleotide 2941: Glu $\rightarrow$ Lys and nucleotide 3031: Val $\rightarrow$ Pro); 2A protein (nucleotide 3294: Ile $\rightarrow$ Met); 2B protein (nucleotide 3724: Asp $\rightarrow$ His and nucleotide 3808: Phe $\rightarrow$ Leu); 3B protein (nucleotide 5268: $\mathrm{Gln} \rightarrow \mathrm{His}$ ) and $-3 \mathrm{D}$ protein (nucleotide 6164: Asp or Asn $\rightarrow$ Gly and nucleotide 7093: Thr $\rightarrow$ Ala). In addition, three other non-exclusive nucleotide changes which led to amino acid substitutions were observed in the $2 \mathrm{C}$ protein (nucleotide 4439: Lys $\rightarrow$ Thr and nucleotide 4871: Asn $\rightarrow$ Ser) and in the polymerase gene (3D) (nucleotide 6555: Ile $\rightarrow$ Met). Six silent nucleotide changes were present in the VP3 protein (nucleotide 1752 shifted from $\mathrm{G} \rightarrow \mathrm{A}$ ), in theVP1 protein (nucleotides 2703 and 2871 mutated from $\mathrm{T} \rightarrow \mathrm{A}=$ and $\mathrm{T} \rightarrow \mathrm{A}$,

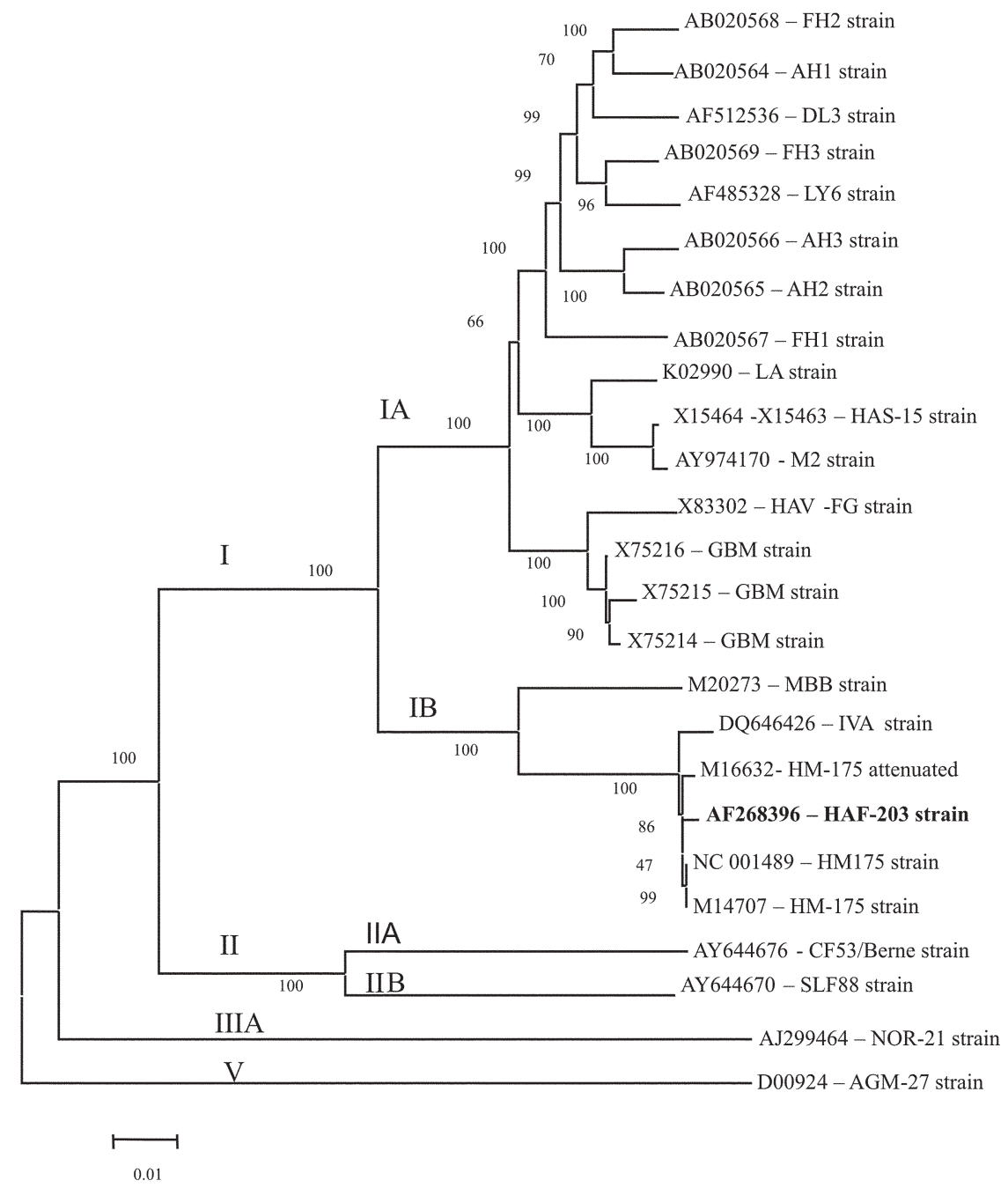

Fig 1: phylogenetic tree based on nucleotide sequence in full-length genome (approximately 7500 nucleotides) from 25 hepatitis A (HAV) virus isolates from different parts of the world compared to the HAF-203 strain, constructed with neighbor-joining method. Roman numerals designate the respective genotype groupings, whereas A and B designate subgenotypes. The numbers at nodes indicate bootstrap percentages after 1000 replications of bootstrap sampling. Genotypes and subgenotypes are indicated at nodes and the horizontal bar indicates genetic distance. Abbreviations and corresponding references are: HAF-203 (this study); FH2, AH1, FH3, AH3, AH2, FH1 (Fujiwara et al. 2001); DL3 (AF512536; Liu et al. unpublished); LY6 (Hu et al. 2002); LA (Najarian et al. 1985); HAS-15 (Sverlov et al. 1987); M2 (AY974170, Badillo et al. unpublished); HAV-FG (Beneduce et al. 1995); GBM (Graft et al. 1994, 1997); MBB (Paul et al. 1987); IVA (DQ646426, Bitchenco et al. unpublished) HM-175, HM-175 attenuated and NC001489 (Cohen et al. 1987a,b); CF53/Berne (Lu et al. 2004); SLF88 (Ching et al. 2002 ) ; NOR-21 (Stene-Johansen et al. 2005); AGM-27 (Tsarev et al. 1991). 
respectively), in the $2 \mathrm{~B}$ protein (nucleotide 3880 was altered from $\mathrm{T} \rightarrow \mathrm{C}$ ) and in the $3 \mathrm{D}$ protein (nucleotide 6232 changed from $\mathrm{T} \rightarrow \mathrm{C}$ and nucleotide 7206 from $\mathrm{A} \rightarrow \mathrm{G})$. Mutations were also witnessed in 5'and 3' untranslated regions (UTRs). However, they were not specific for the HAF-203 strain.

Genetic relationship between $H A F-203$ and other HAV strains - Our results have demonstrated that the HAF-203 strain belongs to genotype IB (Fig. 1). In relation to the genetic diversity, our data suggest that HAF 203 strain presents a high degree of homology with the HM-175 (accession - M14707) and HM-175 attenuated (accession - M16632) strains, with 99.7 and $99.5 \%$ of identity, respectively. Furthermore, an identity of $94.8 \%$ presented itself between HAF 203 and MBB (accession M20273) strains with about $91 \%$ of homology. When the remaining strains were considered (CF53/Berne - accession AY644676; SLF88 accession - AY644670; NOR-21 accession AJ299464, and AGM-27 strains accession D00924), a similarity of $86.3,86,83$, and $81.2 \%$ was observed.

Expression of VP1 in E. coli - We selected the VP1 protein for expression in E. coli since it is the main viral capsid protein from structural and immunogenic standpoints. The recombinant plasmids containing the entire VP1 gene from the HAF-203 strain produced in E. coli was analyzed by SDS-PAGE and Western blot. The expression of a 51 kilodalton $(\mathrm{kDa})$ recombinant protein was observed in bacterial extracts previously transformed with the VP1pET42u plasmid (Fig. 2A). However, the expression of this protein was not detected in bacteria containing the VP1pET85t clone, a plasmid with HAF203 VP1 gene cDNA inserted in the opposite orientation. The yield of recombinant VP1was determined to be approximately $2 \mathrm{mg} / \mathrm{l}$ of bacterial culture (Fig. 2B). In order to investigate the antigenicity of the recombinant VP1, its reactivity with anti-HAV serum was valuated by Western blot (Fig. 2C). The recombinant 51-kDa protein was specifically recognized by human convalescent antiserum to HAV.

Rabbit HAV antiserum - There was a seroconversion of two rabbits immunized with recombinant VP1 protein was analyzed with the Hepanostika HAV Antibody assay (Biomérieux). The OD values of the positive controls ranged from 0.184 to 0.209 whereas those of the negative controls ranged from 0.759 to 0.828 . Anti-HAV sera OD values from the two immunized rabbits were 0.121 and 0.139 , respectively, (cut-off value of 0.495 ). According to dot blot analysis the rabbit HAV antiserum reacted specifically with the HAVAg obtained from tissue culture cells (Fig. 3).

\section{DISCUSSION}
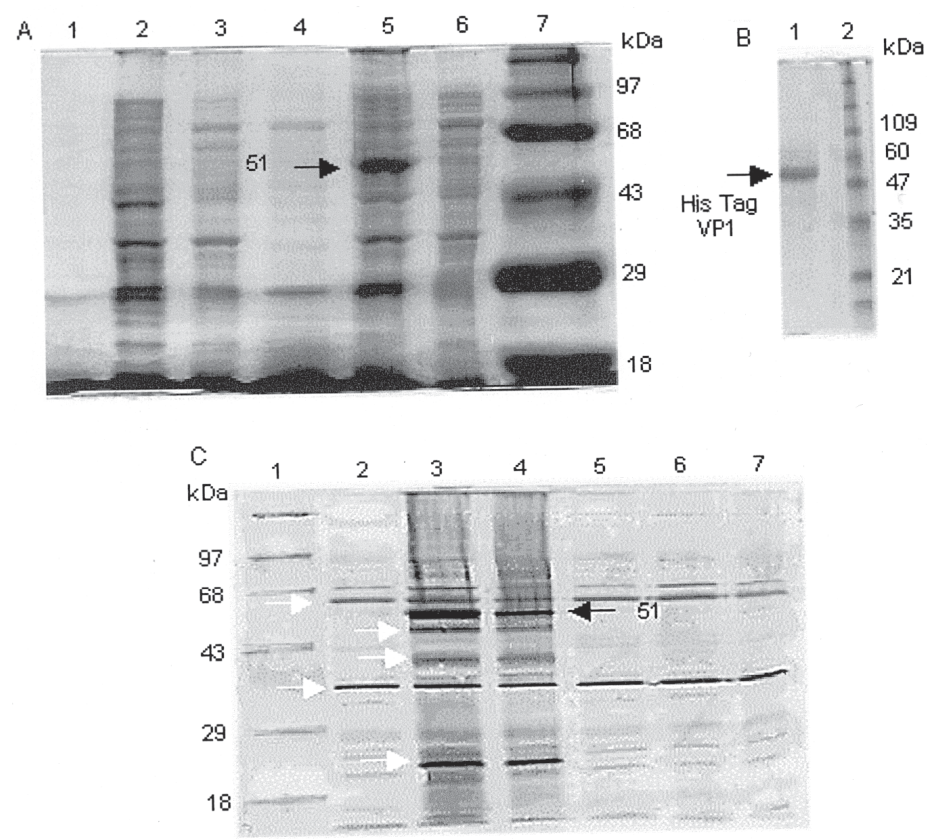

Fig. 2: characterization of recombinant VP1. A: proteins in bacterial lysate were separated by SDS-PAGE. Lanes - 1: supernant; 2: pellet; 3: interface of non-induced culture of Escherichia coli bearing the VP1pET42u plasmid; 4: supernant; 5: pellet; 6: interface correspond to E.coli induced with IPTG; 7: protein molecular weight marker (Invitrogen). The black arrow indicates the 51k-Da recombinant protein expected. B: electrophoretic analysis of recombinant VP1 protein purified by IMAC. Lanes - 1: VP1 recombinant protein; 2: molecular weight marker (Invitrogen). C: western blot analysis of proteins produced by E. coli harbouring VP1pET 42u and VP1pET85t plasmids. Proteins were probed with human convalescent-phase anti-HAV serum. Lanes - 1: protein molecular weight (Invitrogen); 2: VP1pET42u clone non induced; 3: VP1pET42u clone induced with IPTG $0.2 \mathrm{mM}$; 4: VP1pET42u clone induced with IPTG 0.8 mM; 5: VP1pET85t clone non induced; 6: VP1pET85t clone induced with IPTG $0.2 \mathrm{mM}$; 7: VP1pET85t clone induced with IPTG $0.8 \mathrm{mM}$. The black arrow indicates the recombinant protein expected with $51 \mathrm{k}-\mathrm{Da}$ and the white arrows indicate endogenous bacterial proteins $(60$ and $30-35 \mathrm{kDa}$, lane 2) and/or degradation products of the VP1 proteins (45-40-22 $\mathrm{kDa}$, lane 3). 


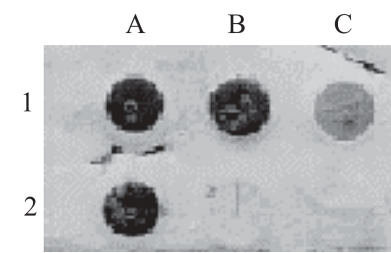

Fig. 3: analysis by Dot Blot. The rabbit antiserum was probed against HAVAg obtained from tissue culture cells (HAF-203 strain). Lanes - $1 \mathrm{~A}$ and $1 \mathrm{~B}$ : HAV purified in $\mathrm{CsCl}$ gradient; $1 \mathrm{C}$ : positive control (supernant from cell culture); 2A: HAV in sucrose cushion; 2B: negative control (cell culture not infected); 2C: negative control (supernatant from cell culture-not infected).

We have sequenced the complete genome of the HAV HAF 203 strain, previously isolated in a cell culture system (Gaspar et al. 1992) in order to assess its genetic variability as compared to other known strains. Mutations were observed along the HAF 203 genome corroborating previous reports in which the authors found mutations scattered throughout the viral genome of HAV strains adapted to cell culture (Najarian et al. 1985, Cohen et al. 1987a,b, 1989, Paul et al. 1987, Graft et al. 1994, 1997, Beneduce et al. 1995). A higher frequency of mutations occurred in the $3 \mathrm{~B}$ region, ranging from 4.3 to $8.6 \%$. The VP1, 2C, and 3D protein genes of HAF-203 displayed non conservative amino acid substitutions, which may have adaptation value for the HAF-203 virus to replicate in cell cultures, but they did not affect its infectivity to non human primates (Vitral et al.1995, Pinto et al.2002).

Ten nucleotide changes led to amino acid substitutions, which are unique in the HAF-203 strain. Those at residues 2292 (VP1), 3294 (2A), and 3808 (2B) led to conservative amino acid substitutions and are not likely to have markedly altered these proteins. However, one nucleotide substitution in the VP3 gene (nucleotide 1574), two in VP1 (at positions 2941 and 3031), one in 2B gene (nucleotide 3724), one in 3B protein (at nucleotide 5268) and two in the 3D protein gene (nucleotides 6164 and 7093) may be relevant to cell culture adaptation. It was also observed that two nucleotide changes in the $2 \mathrm{C}$ protein from the HAF-203 strain (at nucleotides 4439 and at 4871) exhibited the same amino acid substitution as in the HAVFG strain. The mutation at nucleotide 4872 (Asn $\rightarrow$ Met) was correlated to HAV propagation in cell culture (Beneduce et al. 1995). On the other hands, the presence of mutations in the genes encoding 2C, $2 \mathrm{~B}$ (Emerson et al. 1991, 1993) proteins and in 3D protein (Graft et al. 1994) are very common, mainly in strains adapted to cell culture.

The occurrence of deletions and insertions has been reported during the alignment of full-length $\mathrm{HAV}$ genomic sequences. Deletions were observed in the 5 ' $\mathrm{NC}$ region and in VP1 and 3A proteins, while insertions were observed in the $5^{\prime} \mathrm{NC}$ region of the VP1 protein. Beneduce et al. (1995) and Graft et al. (1997) suggested that these findings may be important when isolated HAV is being adapted to cell cultures.
It will be of interest to compare the molecular basis of HAF-203 strain adaptation to FrhK-4 and to a new cellular substrate (certified Vero cells). This virus is now being adapted for growth in Vero cells, with an aim toward the development of an inactivated vaccine against hepatitis A.

A previous report has suggested the existence of at least seven distinct genotypes for HAV (Robertson et al. 1992. In an attempt to better characterize the HAF-203 genotype, its nucleotide sequence was compared to 25 complete nucleotide sequences available in databanks. The HAF-203 strain displays a high degree of homology with HM-175, its attenuated derivative, IVA and MBB strains $(99.7,99.5,98.8$, and $94.8 \%$ respectively), confirming previous data (de Paula et al. 2002, Lu et al. 2004, Stene-Johansen et al. 2005) in which HAF-203 was assigned to genotype IB.

In relation to other isolates (GBM, HAV-FG, M2, HAS15, LA, FH1, AH2, AH3, LY6, FH3, DL3, AH1, and FH2 strains) the level of homology found in comparison with the nucleotide sequence of the HAF-203 strain varied from 91.6 to $90.7 \%$. These strains are classified as genotype IA and they are the most genetically divergent from the HAF203 strain. When our isolate was compared with CF53/ Berne and SLF88, a nucleotide homology of 86.3 and $86 \%$, respectively, was resulted. These strains belong to genotype IIA and IIB, respectively. The level of homology encountered between the NOR-21 and HAF-203 strains in the nucleotide sequence was $83 \%$, NOR-21 being classified as genotype IIIA. Finally, when our isolate was compared with the AGM-27 strain, a nucleotide homology of $81.2 \%$ was observed. These results confirm previous studies in which the AGM-27 strain proved to be unique, because it differs significantly from any other HAV isolate (Lemon et al. 1987, 1992, Tsarev et al. 1991), such as the CF53/Berne, SLF88 and NOR-21 isolates (Ching et al. 2002, Lu et al. 2004, Stene-Johasen et al. 2005).

Our results confirm previous studies where strains from the southern hemisphere, such as HAF-203, HM-175 and $\mathrm{MBB}$, have a very close nucleotide identity while strains from the northern hemisphere are more related to each other. The HAF-203 strain as well as the HM-175 and MBB strains, more than likely, have a common geographic origin.

For the expression of the HAF-203 VP1 protein in $E$. coli two recombinant plasmids carrying the VP1 gene were constructed. Our results revealed that human serum recognized the 51k-Da recombinant protein present in E. coli extracts in contrast with a previous report (Ostermayer et al. 1987), which claimed that VP1 in E. coli was not antigenic. Two bands of approximately 60 and $30-35 \mathrm{kDa}$ probably reflect recognition of endogenous bacterial proteins by the human serum. The other bands (45-40-22 kDa) might correspond to degradation products of the VP1 protein expressed in E. coli as suggested by Johnston et al. (1988).

Previous studies have demonstrated that either VP1 (Stapteton \& Lemon 1987) or VP3 (Ping et al. 1988) proteins contain the most important neutralization epitopes in the HAV virion. Recombinant HAV VP1 and VP3 expressed in $E$. coli have also proven to be antigenic in 
rabbits (Johnston et al. 1988, Gauss-Müller et al. 1990, Powdrill et al. 1991).

We have immunized rabbits with the recombinant VP1 protein and the resulting antiserum was conjugated to peroxidase. Our results indicate that the anti HAV rabbit sera peroxidase conjugate may be applied, after appropriate standardization, as a reagent in a competitive enzyme immunoassay for HAV infection diagnosis.

\section{ACKNOWLEDGMENT}

To Dr José Antônio Pinto Sá Ferreira (Diagnosis Reactive Department of Bio-Manguinhos-Fiocruz) for his help in reviewing the manuscript. Reviewed and revised by Mitchell Raymond Lishon, native of Chicago, Illinois, US, UCLA 1969.

\section{REFERENCES}

Beneduce F, Pisani G, Divizia M, Panà A, Morace G 1995. Complete nucleotide sequence of a cytophatic hepatitis A virus strain isolated in Italy. Virus Res 36: 299-309.

Camargo F, Gaspar AMC, Yoshida CFT 1987. Comparative Elisa reagents for detection of hepatitis $\mathrm{B}$ surface antigen (HBsAg). Mem Inst Oswaldo Cruz 82: 181-187.

Ching KZ, Nakano T, Chapman LE, Demby A, Robertson BH 2002. Genetic characterization of wild-type genotype VII hepatitis A virus. J Gen Virol 83: 53-60.

Cohen JI, Rosenblum B, Feinstone SM, Ticehurst J, Purcell RH 1989. Attenuation and cell culture adaptation of hepatitis A virus (HAV): a genetic analysis with HAV cDNA. J Virol 63: 5364-5370.

Cohen JI, Rosenblum B, Ticehurst JR, Daemer RJ, Feinstone SM, Purcell RH 1987a. Complete nucleotide sequence of an attenuated hepatitis A virus: comparison with wild-type virus. Proc Natl Acad Sci USA 84: 2497-2501.

Cohen JI, Ticehurst JR, Purcell RH, Buckler-White A, Baroudy BM 1987b. Complete nucleotide sequence of wild-type hepatitis A virus: comparison with different strains of hepatitis A and other picornaviruses. J Virol 61: 50-59.

Coulepis AG, Tannock GA, Locarnini SA, Gust ID 1981. Evidence that the genoma of hepatitis A virus consists of singlestranded RNA. J Virol 37: 473-477.

De Paula VS, Baptista ML, Lampe E, Niel C, Gaspar AMC 2002. Characterization of Hepatitis A virus isolated from subgenotypes IA and IB in Rio de Janeiro, Brazil. J Med Virol 66: 22-27.

Di Napoli A, Maltese E, Bucci M, Pagnotti P, Seipelt J, Duquerroy S, Perez Bercoff R 2004. Molecular cloning, expression and purification of protein 2A of hepatits A virus. New Microbiol 27: 105-112.

Emerson SU, McRill C, Rosenblum B, Feinstone S, Purcell RH 1991. Mutations responsible for adaptation of hepatitis A virus to efficient growth in cell culture. J Virol 65: 4882-4886.

Emerson SU, Huang YK, Purcell RH 1993. 2B and 2C mutations are essential but mutations throughout the genome of HAV contribute to adaptation to cell culture. Virology 194: 475480 .

Feinstone SM, Kapikian AZ, Purcell RH 1973. Hepatitis A: detection by immune electron microscopy of a virus-like antigen associated with acute illness. Science 182: 10261028 .
Fujiwara K, yokosuka O, Fukai K, Imazeki F, Saisho H, Omata M 2001. Analysis of full-length hepatitis A virus genome in sera from patients with fulminant and self-limited acute type A hepatitis. J Hepatol 35: 112-119.

Gaspar AMC, Vitral CL, Yoshida CFT, Schatzmayr HG 1992. Primary isolation of a brazilian strain of hepatitis A virus (HAF-203) and growth in a primate cell line ( FRhK-4). Brasilian J Med Biol Res 25: 697-705.

Gauss-Müller V, Zhou MQ, von der Helm K, Deinhardt F 1990. Recombinant proteins VP1 and VP3 of hepatitis A virus prime for neutralizing response. J Med Virol 31: 277-283.

Graff J, Normann A, Feinstone S, Fhehmig B 1994. Nucleotide sequence of wild-type hepatitis A virus GBM in comparison with two cell culture-adapted variants. J Virol 68: 548554.

Graft J, Normann A, Flehmig B 1997. Influence of the 5' noncoding region of hepatitis A virus strain GBM on its growth in diferrent cell lines. J Gen Virol 78: 1841-1849.

Hebert GA, Pelham OL, Pittman B 1973. Determination of the optimal ammonium sulphate comcentration for the fractionation of rabbit, sheep, horse and goat antisera. Appl Microb 25: 26-36.

$\mathrm{Hu}$ Y, Hu N, Liu G 2002. Complete genomes of two human hepatitis A virus isolates from China: analysis and comparison with other isolates. Acta Virol 46: 153-157.

Johnston JM, Harmon AS, Binn LN, Richards OC, Ehrenfeld E, Summers DF 1988. Antigenic and immunogenic properties of hepatitis A virus capsid protein expressed in Escherichia coli. J Infec Dis 157: 1203-1210.

Kumar S, Tamura K, Niel M 2004 Mega 3: integrated software for molecular evolutionary genetics analysis and sequence alignment. Brief Bioinform 5: 150-163.

LaBrecque FD, Labrecque DR, Klinzman D, Perlman S, Cederna JB, Winokur PL, Han JQ, Stapleton JT 1998. Recombinant hepatitis A virus antigen: improved production and utility in diagnosis immunoassays. J Clin Microbiol 36: 2014-2018.

Lemon SM, Chao SF, Jansen RW, Binn LN, LeDuc JW 1987. Genomic heterogeneity among human and non-human strains of hepatitis A virus. J Virol 61: 735-742.

Lemon SM, Jansen RW, Brown EA 1992. Genetic, antigenic and biological differences between strains of hepatitis A virus. Vaccine 10: 40-44.

Lowry OH, Rosebrough NJ, Farry AL, Randall RJ 1951. Protein measurement with the Folin phenol reagent. J Biol Chem 193: 265-275.

Lu L, Ching KZ, de Paula VS, Nakano T, Siegl G, Weitz M, Robertson BH 2004. Characterization of the complete genomic sequence of genotype II hepatitis A virus (CF53/ Berne isolate). J Gen Virol 85: 2943-2952.

Minor P 1991. Classification and nomenclature of viruses. In RIB Franki, CM Fauquet, DL Knudson, F Brown (eds), Fifth Report of the International Committee on Taxonony of Viruse. Arch Virol 2: 320-326.

Najarian R, Caput D, Gee W, Porter SJ, Renard A, Merryweather J, Van Nest G, Dina D 1985. Primary structure and gene organization of human hepatitis A virus. Proc Natl Acad Sci USA 82: 2627-2631. 
Ostermayr R, von der Helm K, Gauss-Müller V, Winnacker EL, Deinhardt F 1987. Expression of hepatitis A virus cDNA in Echerichia coli: antigenic VP1 recombinant protein. J Virol 61:3645-3647.

Paul AV, Tada H, von der Helm K, Wissel T, Kiehn R, Wimmer E, Deinhardt F 1987. The entire nucleotide sequence of the genome of human hepatitis virus (isolate MBB). Virus Res 8: 153-171.

Ping LH, Jansen RW, Stapleton JT, Cohen JI, Lemon SM 1988. Identification of an immunodominant antigenic site involving the capsid protein VP3 of hepatitis A virus. Proc Natl Acad Sci USA 85: 8281-8285.

Pinto MA, Marchevsky RS, Baptista ML, de Lima MA, PelajoMachado M, Vitral CL, Kubelka CF, Pissurno JW, Franca MS, Schatzmayr HG, Gaspar AM 2002. Experimental hepatitis A virus (HAV) infection in Callithrix jacchus: early detection of HAV antigen and viral fate. Exp Toxicol Pathol 53: 413-20.

Powdrill TF, Johnston JM 1991. Immunologic priming with recombinant hepatitis A virus capsid protein produced in E.coli. J Virol 65: 2686-2690.

Robertson BH, Jansen RW, Khanna B, Totsuka A, Nainan OV, Siegl G, Widell A, Margolis HS, Isomura S, Ito K, Ishizu T, Moritsugu Y, Lemon SM 1992. Genetic relatedness of hepatitis A virus strains recovered from different geographical regions. J Gen Virol 73: 1365-1377.

Saiki RK, Arnhein N, Erlich HÁ 1988. A novel method for the detection of polymorphic sites clivage of oligonucleotide probes: aplication to sick-cell anemia. Biotechnology 3: 10081012.

Sanger F, Nicklen S, Coulson R 1977. DNA sequencing with chain-terminating inhibitors. Proc Natl Acad Sci USA 74: 5463-5467.
Stapteton JT, Lemon SM 1987. Neutralization escape mutants define a dominat immunogenic neutralization site on hepatitis A virus. J Virol 61: 491-498.

Stene-Johansen K, Jonassen TO, Skaug K 2005. Characterization and genetic variability of Hepatitis A virus genotype IIIA. J Med Virol 86: 2739-2745.

Sverdlov SD, Tsarev SA, Markova SV, Vasilenko SK, Chizhikov VE, Petrov NA, Kusov YuYu, Nastashenko TA, Balayan MS 1987. Cloning and expression of hepatitis A virus genome in E. coli cells. Mol Gen Microbiol Virol 6: 129-133.

Ternovai VA, Bondarenko Tiu, Bondarchuk VB, Maidaniuk AG, Netesov SV 2001. Expression of hepatitis A virus recombinant proteins in Escherichia coli. Zh Mikrobiol Epidemiol Immunobiol Mar-Apr: 76-80.

Thompson JD, Gibson TJ, Plewniak F, Jeanmougin F, Higgins DG 1997. The clustal X windows interface: flexible strategies for multiple sequence alignment aided by quality analysis tools. Nucleic Acids Research 24: 4876-4882.

Tsarev SA, Emerson SU, Balayan MS, Ticehurst JR, Purcell RH 1991. Simian hepatitis A virus (HAV) strain AGM-27: comparison of genome structure and growth in cell culture with other HAV strains. J Gen Virol 72: 1677-1683.

Vitral CL, Gaspar AMC, Yoshida CFT 1991. Two competitive enzyme immunoassays for the detection of IgG class antibodies to hepatitis A antigen. Rev Soc Bras Med Trop 24: 79-85.

Vitral CL, Marchevsky RS, Yoshida CFT, Coelho JMCO, Gaspar AMC, Schatzmayr HG 1995. Intragastric infection induced in marmosets (Callithrix jacchus) by a brazilian hepatitis A virus (HAF-203). Brazilian J Med Biol Res 28: 313-321. 